\author{
JAN OLASZEK \\ https://orcid.org/0000-0002-7700-3256 \\ Institute of Political Studies \\ of the Polish Academy of Sciences, Warsaw
}

\title{
UNDERGROUND PUBLISHING, SAMIZDAT AND CENTRAL EUROPE*
}

Abstract: The review article deals with participation of independent media in the debate on the notion of Central-Eastern Europe in Czechoslovakia and Poland. Participants of this debate (Polish, Czech and Slovak writers, intellectuals and journalists) symbolically neutralized the cold-war division of the world (iron curtain) and liquidated barriers between socialist countries being the parts of the Soviet empire.

Keyw ords: PRL, Czechoslovakia, samizdat, underground circulation network, Central Europe, Central and Eastern Europe.

Dissident movements, in particular various states of the Soviet bloc and their underground publishing activity, are usually described separately; neither of these two subjects has so far received a transnational synthesis. ${ }^{1}$ A comparative approach is also rare. An important contribution a broader approach of this form to the subject is a recently published book by Weronika Parfianowicz-Vertun, which deals to a great extent with the Polish independent publishing movement, and 'samizdat' developed in Czechoslovakia. It is not a typical historical book, since it was prepared based on a doctoral dissertation in cultural studies. This is central to its manner of description and analysis of the

* Weronika Parfianowicz-Vertun, Europa Środkowa w tekstach i działaniach: Polskie i czeskie dyskusje [The Notion of Central Europe in Texts and Actions: Polish and Czech Debates], Warsaw: Wydawnictwa Uniwersytetu Warszawskiego, 2016, 430 pp., Communicare: Historia i Kultura.

${ }^{1}$ Łukasz Kamiński, 'Opozycja w Europie Środkowo-Wschodniej w latach 19451989 - droga do syntezy dziejów', in Opozycja antykomunistyczna w krajach bloku wschodniego w latach 1945-1989, ed. Krzysztof Łabędź and Małgorzata Świder, Cracow, 2014, pp. 9-19 (p. 10); Przemysław Gasztold-Seń, Natalia Jarska and Jan Olaszek, 'Wstęp', in Drugi obieg w PRL na tle samizdatu w państwach bloku sowieckiego po 1956 roku, ed. iidem, Warsaw, 2016, p. 9. A publication, which can aspire to be a synthesis of the history of samizdat is the book by H. Gordon Skilling, Samizdat and an Independent Society in Central and Eastern Europe, Columbus, OH, 1989; but its author devotes a disproportionate portion of his analysis to Czechoslovakia. 
theme. A reader who is interested in the history of clandestine magazines and publications, including texts on Central Europe, will not find much information on it in this book. This is neither a book on the backstage mechanics of samizdat and underground publishing, nor a work on the history of ideas, instead concentrating exclusively on a detailed analysis of the texts published underground and dealing closely with the themes mentioned in its title.

What then does Europa Środkowa w tekstach i działaniach deal with? Weronika Parfianowicz-Vertun describes her scope of research as follows: 'I will be interested in a narrow section of this debate [about Central Europe - J.O.], namely, the discussions on Central European issues which took place in the 1970s and 1980s concerning underground publications in Poland and Czechoslovakia - their development, particulars, circulation, content and the movements' participants' (p. 16). ${ }^{2}$ Such a proposed scope to the subject is still within the bounds of a typical historical approach. But the author broaches the separate threads she mentions differently than most historians would probably do. The development of debates about the form of Central Europe is not described in this book chronologically. It has not been divided into separate chapters and sections relating to the different environments for which the debates were relevant, or to particular topical aspects of these debates (such as historical, political, cultural or social issues). Although the author declares her interest in the participants of the discussions on Central European independent press, she gives no more description of the circles which created the most important magazines publishing articles on this subject. These threads are missing and that makes it more difficult to understand the narrative, especially with respect to Poles having taken part in these debates. In order to understand their development, readers should be given at least some basic information on the people who have participated in them.

Instead, Parfianowicz-Vertun proposes her own original approach. She is not so much interested in the participants in the debates on the idea of Central Europe as individuals, but in the social and cultural aspects of these peoples' activities and the functioning of their writings. Her approach seems to be situated at an intersection of the history of ideas and cultural anthropology. Among Polish historians having written about independent publishing, the author - as she emphasizes herself (p. 84) - is closest to Paweł Sowiński and his Zakazana ksiażka (A Forbidden Book), in which he presented a sociological-anthropological portrait of the groups of people who drove the circulation of free word in the Polish People's Republic (PRL). ${ }^{3}$ It seems that Parfianowicz-Vertun - much like Sowiński - has assumed that the basic facts from the history of the initia-

2 'interesować mnie będzie wąski wycinek tej debaty [o Europie Środkowej J.o.], a mianowicie dyskusje poświęcone problematyce środkowoeuropejskiej toczone w latach 70. i 80. XX wieku na łamach nieoficjalnych wydawnictw w Polsce i Czechosłowacji - ich przebieg, specyfika, obiegu, treść i uczestnicy'.

${ }^{3}$ See: Paweł Sowiński, Zakazana książka: Uczestnicy drugiego obiegu 1977-1989, Warsaw, 2011. 
tives she describes are well known to the readers, or are not necessary in order to understand the analysis she conducts. One may have doubts as to the correctness of this assumption, since the history of Polish and Czechoslovakian press focusing on Central Europe has not been subject to much in-depth research or detailed description. But it is possible that an extended discussion and detailed description of the history of members of the underground press who initiated the developments discussed by the author, could cause the main asset of this book to be lost in a mass of non-essential information.

The originality of Parfianowicz-Vertun's approach lies in her interest in the perceptions of Central Europe, which she sets out in the context of how they were described, created and propagated. If we try to state briefly what the author is most interested in, it would be 'cultural practices'. She writes of her perspective in the following way: 'This approach assumes that interpretation of particular texts on Central Europe is not enough; it is necessary to try to reconstruct the way (often not evident), in which these texts functioned in different environments, who the readers were and what were their references for interpreting the texts, and with what non-written practices can these texts be linked. It will emerge that the same text can radically change its meaning with a change of the circulation network in which it was created' (p. 65). ${ }^{4}$ The author's research corresponds with research on 'writing practices' developed by anthropologists. So her interest is focused not on the discourse itself relating to Central Europe but on its function - as put by Grzegorz Godlewski, whom Parfianowicz-Vertun quotes 'embedded in the network of versatile and changeable cultural conditions'. Pursuing this approach she treats independent press not only as a conveyor of message, but (again in accordance with Godlewski's approach) - as 'communication environments'; this allows for observing not just the statements made by independent press, but their real function, the relationships between the discourse's participants, its range, and a wide spectrum of similar concerns (p. 27). Such approach should be considered innovative, since Polish historiography on the publishing output of democratic opposition and independent culture has been dominated by analyses of political thought using clandestine publications as source material (and independent from study of their practices), and works providing detailed reconstructions of facts concerning particular editorial groups or publishing houses. Reading this book is a convincing argument for both these areas to be studied in parallel and not discrete from each other.

Underground publishing, samizdat and Central Europe - Parfianowicz-Vertun focuses her analyses around these three concepts. Why has she chosen to look at the debates on the idea of Central Europe through the lens of Polish

4 'Podejście to zakłada, że nie wystarczy interpretacja poszczególnych tekstów poświęconych Europie Środkowej, ale konieczna jest też próba rekonstrukcji (często nieprzejrzystego) sposobu, w jaki teksty te funkcjonowały w różnych środowiskach, kim byli ich czytelnicy i w odniesieniu do czego mogli je interpretować, z jakimi pozatekstowymi praktykami możemy je powiązać. Okaże się, że ten sam tekst mógł radykalnie zmieniać znaczenia wraz ze zmianą obiegu, w którym zaistniał'. 
underground publishing and Czechoslovakian samizdat? Several factors were central to the author's decision. As she rightly states, it was the circulation of free words which has constituted the most important space of debates on this subject in the Central European region (p. 69). Hitherto their development had been reconstructed mainly based on a certain closed and rather limited canon of texts written mostly by people from the West (such as Timothy Garton Ash's essay 'Does Central Europe Exist?', New York Review of Books, 9 October 1986) or by emigrants (the famous text by Milan Kundera, 'The Tragedy of Central Europe', New York Review of Books, 26 April 1984).

The author points out that when texts published underground in the communist states are analysed in studies, such analysis usually relates to the few best known statements which were quickly reprinted on the other side of the Iron Curtain and circulated in separation from their specific communication channel - the underground publishing and samizdat. In Parfianowicz-Vertun's opinion, 'the project of Central Europe' included not only texts but also activities (it was not accidental that this word was used in the title of the book): 'Underground and samizdat magazines allow for specific tracing how "Central Europe is created", since this creation involves not only intellectual work, but also has a very specific material form and is entangled in a network of different practices, which, being a kind of media revolution, bring the underground publishing movement to the surface' (p. 70). ${ }^{5}$

An analysis of texts published in clandestine magazines would be weak if the author removed it from the context of debates taking place in other forums. The free press did not circulate in a vacuum. It was not intended to replace other circles of communication but rather to operate next to them. Parfianowicz-Vertun is right not to omit these other networks, such as emigrant magazines (she writes a lot about the Parisian Kultura or the Czech emigration magazine Svědectví) and official ones (she mentions important texts published in Poland, for example in Tygodnik Powszechny and Res Publica, published officially since 1987). She does not forget the role of untranscribed oral debates, taking note of different conferences and seminars on the idea of Central Europe.

But what was the reason that the author decided to write about the Polish People's Republic and Czechoslovakia (besides that of her competences, since she specializes in (zech culture)? Of the other states which form a part of the Central Europe project and in which the free press movement developed in the last decades of communism, Hungary is notable. The book contains references to Hungarian samizdat and they form a material context; nevertheless, it is the publishing activity of dissidents from Poland and Czechoslovakia that constitutes the main subject of the author's interest. 'This choice is dictated

5 'Czasopisma drugoobiegowe i samizdatowe w sposób szczególny pozwalają prześledzić, jak "tworzy się Europę Środkową". To wytwarzanie ma bowiem nie tylko charakter intelektualnej pracy, lecz także bardzo konkretną materialną postać i jest uwikłane w sieć bardzo różnych praktyk - które będąc swego rodzaju medialną rewolucją - nieoficjalny ruch wydawniczy wydobywają na powierzchnię'. 
not only by the intensity of dispute about Central Europe in these two countries, the multitude of projects related to this subject, or the agency of Polish and Czech intellectuals in initiating debates of international range, but also the numerous points of flow and cooperation between Polish and Czech environments' - she explains (p. 16). ${ }^{6}$ In this context she refers, for example, to the history of the famous Karkonosze mountain meetings of Polish and Czechoslovakian political opposition in the 1970s. ${ }^{7}$ Czechoslovakian samizdat was one of the key sources of inspiration for Polish authors of independent magazines, which is reflected in many Czech connections among Polish underground publishing, previously described by Dorota Bielec (and cited in Parfianowicz-Vertun's book). ${ }^{8}$ This interest was mutual at the time. ${ }^{9}$ The author calls these contacts 'practising the idea of Central Europe'. Contacts between dissidents which created - beyond differences and conflicts - a special 'republic of friends' facilitated implementation of projects on which so many people have written. Observation of these practical attempts at realizing the idea of Central Europe is one of the major values of this book.

This is reflected in the structure of the work. The book has four chapters. The first of them ('Europa Środkowa jako problem badawczy' - Central Europe as a Research Problem) is in fact a highly developed introduction, in which the author explains her approach to the idea of Central Europe as a form of project. This theme could deserve a much broader review, since debates on it continued for a long time and have been subject to numerous analyses. The author - understandably not wanting to repeat problems described already many times in literature - analyses the threads of the discussion on Central Europe directly relevant to the problems she is interested in. She is right when she states that 'Central Europe' refers to an idea rather than to reality (p. 20) since the borders of Central Europe (often called in Poland 'Central and Eastern Europe') are so variable according to the chosen perspective that - as Tomasz Kizwalter emphasized - it was 'an imagined region', which existed 'rather in human minds than in geographic and social-economic reality. ${ }^{10}$ Parfianowicz-Vertun has understood this perfectly and this is why she treats Central Europe first of all as a project.

6 'Za tym wyborem przemawia nie tylko intensywność sporów wokół Europy Środkowej w tych dwóch krajach, wielość przedsięwzięć związanych z tym tematem, czy udział polskich i czeskich intelektualistów w inicjowaniu debat o międzynarodowym zasięgu, lecz także liczne punkty przepływu i współpracy między polskimi i czeskimi środowiskami'. The author specifies that she is much more interested in samizdat created by Czechs, since Slovak dissidents wrote less about this subject.

${ }^{7}$ Here she could benefit from the broader scope of literature on this subject, see, for example: Łukasz Kamiński, Petr Blažek and Grzegorz Majewski, Ponad granicami: Historia Solidarności Polsko-Czechosłowackiej, Wrocław, 2009.

${ }^{8}$ See: Dorota Bielec, Sprawy czeskie w polskich drukach drugiego obiegu, Cracow, 2008.

${ }^{9}$ See: Česká a polská samizdatová literatura / Czeska i polska literatura drugiego obiegu, ed. Libor Martinek and Martin Tichý, Opava, 2004.

10 "chodzi tu o historię "regionu wyobrażonego", zakorzenionego raczej w umysłach ludzkich niż w realiach geograficznych i społeczno-gospodarczych', Tomasz Kizwalter, “"Zachód porwany...”, KH, 120, 2013, 4, pp. 825-31 (p. 828). 
In the following chapter titled 'Europa Środkowa w kontekście nieoficjalnych obiegów kultury' (Central Europe in the Context of Non-Official Circulations of Culture) Parfianowicz-Vertun analyses underground publishing in Poland and samizdat in Czechoslovakia. Her analysis is often set in the context of debates about the idea of Central Europe, but is also interesting in regard to the circulation networks of the free press. The next two chapters relate directly to 'Central-European' debates ('Czeskie spojrzenia na Europę Środkową' and 'Polskie dyskusje wokół pojęcia Europy Środkowej' - Czech Perceptions of Central Europe and Polish Discussions on Central Europe Concept). The book is ends with a final section slightly disappointing in to its length (less than three pages) and a lack of clear conclusions from the work. Many interesting theses and reflections of the author which appear in the book deserve exposure in this last part. In particular a clearly formulated conclusion is needed as the impact had on the debates on Central Europe described by the author by their particular 'uncensored character'.

Parfianowicz-Vertun has used extensive and varied literature on this theme. We can find references to publications from different areas of humanities and social sciences written by well-known authors, both foreign (such as Michel Foucault, Eric Hobsbawm, Tony Judt and Hayden White, and Marci Shore - representative of the younger generation), and Polish (Bogusław Bakuła, Michał Głowiński, Jerzy Jedlicki, Marcin Kula, Andrzej Mencwel and Krzysztof Pomian). The selection of literature and her use of it showcases Parfianowicz-Vertun's broad horizons and erudition. She refers to works from fields including anthropology, the history of literature, the history of ideas, sociology and philosophy, which generally bring important theoretical material then used by the author, or referring specifically to the problem of Central Europe as an idea. Taking into account the large volume of publications on the latter issue, ${ }^{11}$ Parfianowicz-Vertun's choice of literature on this subject has had to be selective, but it seems sufficient for the analysis chosen by the author.

It's possible to be more critical about the use of historiography relating to communist rule in Poland and Czechoslovakia and the forms of protest against it. Particularly the works of historians dealing with opposition circles in the Polish People's Republic and Polish independent publishing movements have been used in a sketchy way in this book. Many studies have been omitted. The most significant (considering the book's theme of 'Central Europe') is Andrzej Friszke's article on socio-cultural underground magazines in the PRL, ${ }^{12}$ and the books by Małgorzata Choma-Jusińska on the Lublin opposition (in which much is written about Spotkania (Meetings) a magazine which to

${ }^{11}$ On this subject see, for example, answers to the survey on usefulness of the notion of Central Europe (or Central-Eastern Europe) published in KH, 120, 2013, 4, pp. 793-919.

${ }^{12}$ Andrzej Friszke, 'Czasopisma społeczno-kulturalne "drugiego obiegu” wydawniczego', in Czasopisma społeczno-kulturalne w okresie PRL, ed. Urszula Jakubowska, Warsaw, 2012, pp. 383-462. 
a certain extent specialized in the subject of Central Europe), ${ }^{13}$ Łukasz Jasiński on international affairs in the publications of the pre-August opposition, ${ }^{14}$ and Andrzej Kobus on the relations of Polish opposition circles with dissident movements in other states of the Soviet bloc. ${ }^{15}$ This would introduce mention of numerous examples of Polish-Czechoslovak underground contacts both, in exchange of ideas and practical activity. A reader unfamiliar with history of the opposition would better understand the phenomenon of 'practising Central Europe' which the author describes.

Another significant shortcoming is lack of reference to the research of Padraic Kenney, ${ }^{16}$ who extensively discusses the trans-border flow of ideas among opposition movements in the Soviet bloc countries. It is the best study of 'practising the idea' of Central Europe. The third striking omission is the text by Rüdiger Ritter about the problem of Europe and discussion about eastern neighbours of Poland in the underground magazines. ${ }^{17}$

On the other hand, the extent of Parfianowicz-Vertun's use of literature relating to Czech dissident circles is impressive, although it is possible to point to publications which were unjustly omitted. The author referred only to one text by Petr Blažek, who wrote many texts about the history of the opposition in Czechoslovakia and its relations with Poland. ${ }^{18}$ Another, even more useful, would be Petr Poslední's text on Czech-Polish literary relations in the seventies. ${ }^{19}$ There is no reference to the text by Albert Kulla and Imrich Gazda about the history of Czechoslovakian samizdat, ${ }^{20}$ or to Tomáš Glanc's article, ${ }^{21}$ in which he specially described the medium of samizdat, which would be worth mentioning given Parfianowicz-Vertun's declared interest in the relation

${ }^{13}$ Małgorzata Choma-Jusińska, Środowiska opozycyjne na Lubelszczyźnie 1975-1980, Warsaw and Lublin, 2009.

${ }^{14}$ Łukasz Jasiński, Kwestie międzynarodowe w myśli opozycji demokratycznej w PRL 1976-1980, Gdańsk, 2009.

${ }^{15}$ Andrzej Kobus, My i oni: Opozycja polityczna w PRL wobec analogicznych ugrupowań demokratycznych $w$ Europie Środkowo-Wschodniej lat 80. XX wieku: Kontakty, wspótpraca, podobieństwa, Łódź, 2012.

${ }^{16}$ Padraic Kenney, A Carnival of Revolution: Central Europe 1989, Princeton, NJ, 2002 (Polish edition 2005).

${ }^{17}$ Rüdiger Ritter, 'Preparing the Postcolonial Situation: Polish Drugi Obieg Periodicals, the Europe Topic and the Question of Poland's Eastern Europe', Porównania, 13, 2013, pp. 61-79.

${ }^{18}$ Petr Blažek, 'Solidarita se Solidaritou: Opoziční hnutí v Československu a vyhlášení polského “válečného stavu” v prosinci 1981', in Od rywalizacji do wspótpracy: Relacje polsko-czeskie w badaniach młodych historyków z Polski i Republiki Czeskiej, ed. Dariusz Dąbrowski, Wrocław, 2003, pp. 245-65.

${ }^{19}$ Petr Poslední, 'Czesko-polski kontekst literacki (1970-1979)', Porównania, 7, 2010, pp. 97-111.

${ }^{20}$ Albert Kulla and Imrich Gazda, 'Samizdat Periodicals before 1989 in Former Czechoslovakia', in Advances in Communication and Mass Media Research, ed. Yorgo Pasadeos, Athens, GA, 2010, pp. 35-43.

${ }^{21}$ Tomáš Glanc, 'Samizdat jako médium', Souvislosti, 2013, 3, pp. 183-93. 
between the creation and distribution of independent publications, and their content. Publications describing the samizdat phenomenon in the context of the entire Soviet bloc are treated very briefly. ${ }^{22}$

A broader source inquiry would certainly not result in a radical change of the book's theses. A broader use of scientific literature would allow for observing some material contexts of the debates which have been analysed, and to mention some unused sources. Particularly noticeable with respect to source publications omitted by the author and containing articles published in the uncensored magazines in Poland and Czechoslovakia are a volume compiled by Marketa Goetz-Stankiewicz, which contains a text (absent in Parfianowicz-Vertun's discussion) significantly titled 'We Central East Europeans', ${ }^{23}$ and an anthology prepared by Jan Skórzyński. ${ }^{24}$

Parfianowicz-Vertun shows her expertise writing about the Czech texts on Central Europe. She does not discuss the well-known writing of Kundera, and instead concentrates on three other authors. The first one is Karel Kosík, a philosopher and one of the first revisionist Marxists in Czechoslovakia who was deprived of the right to publish from the 1970s. He wrote about Central Europe in the convention of a tragedy stemming from a trauma, which for his generation meant the invasion of Czechoslovakia by armies of the Warsaw Pact. Sociologist Vaclav Belohradský was more optimistic: he pointed to the role of the dissident movements as reactions to the crisis of Western civilization. The author Josef Kroutvor, who had emigrated to France in 1968, wrote about Central Europe in the convention of grotesque and parody. Except for Kosík's text, these essays were reprinted in Poland by the independent publishing system. Parfianowicz-Vertun indicates that the Czech reception of Central Europe is characterized by

${ }^{22}$ See: Underground Publishing and the Public Sphere: Transnational Perspectives, ed. Jan C. Behrends, Thomas Lindenberger, Wien and Münster, 2014; Samizdat, Tamizdat, and Beyond: Transnational Media During and After Socialism, ed. Frederike Kind-Kovács and Jessie Labov, New York and Oxford, 2012. Shortly before publication of Parfianowicz-Vertun's book the following works were published: Gregor Feindt, Auf der Suche nach politischer Gemeinschaft: Oppositionelles Denken zur Nation im ostmitteleuropäischen Samizdat 1976-1992, Berlin, 2015 (Feindt writes quite a lot about the vision of Central Europe presented in the samizdat magazines); Ann Komaromi, Uncensored: Samizdat Novels and the Quest for Autonomy in Soviet Dissidence, Evanston, IL, 2015.

${ }^{23}$ Miroslav Kusý, 'We Central East Europeans', in Good-bye, Samizdat: Twenty Years of Czechoslovak Underground Writing, ed. Marketa Goetz-Stankiewicz, Evanston, IL, 1992, pp. 160-65. Weronika Parfianowicz-Vertun mainly writes about Czech authors, and Kusý was a Slovak, however, it seems that taking into account his text would be useful.

${ }^{24}$ Na przekór geopolityce: Europa Środkowo-Wschodnia w myśli politycznej polskiej opozycji demokratycznej 1976-1989, ed. Jan Skórzyński, Warsaw, 2014. Overlooking this anthology results in the fact that Parfianowicz-Vertun did not take into account several important articles contained in it and was unable to decode the pen name 'Piotr Radkunas' (the author whom she refers to several times, and who published in the Polish magazine ABC: Adriatyk - Bałtyk - M. Czarne (ABC: The Adriatic - the Baltic Sea - the Black Sea)). This was the penname of Zygmunt Komorowski, father of a an oppositionist Bronisław Komorowski, later a politician in the Third Republic of Poland. 
its Czech-centrism: Czechs are perceived as the centre of the continent, an intermediary of cultures. At the same time she emphasizes that the authors who wrote about this in samizdat publications were not uncritical. They described the tension between the stereotype of 'the small, Czech man' preoccupied with everyday matters, and a heroic, elevated vision of Czech identity.

As far as the Polish vision of Central Europe is concerned, it has been mainly constructed based on the magazines which specialized in foreign themes. The book firstly displays the tension between a perspective derived from the Parisian Kultura and absorbed by much of the democratic opposition, and nostalgia regarding the eastern borderlands which was also present in the identity of the movement. As with the Czechs, Polish discussions were characterized by having their own country placed at the centre. The author also suggests that these debates were characterized by a faintly patronizing tone regarding other nations, for example towards Lithuania. In my opinion it is difficult to find a convincing source of evidence to support this conclusion in the book.

Parfianowicz-Vertun mentions that Polish authors had differing opinions on the role of Russia. On one hand it has been viewed as a common enemy uniting smaller nations and on the other, as a factor playing them off against each other. In Polish narratives on Central Europe, as she rightly notes, an important role was played by the portrayal of the intellectual as a man with a mission or obligation toward the nation. Dissidents were viewed as being yet another embodiment of this narrative, whereas such an element was not really present in the Czech tradition and so it was not reflected in samizdat.

The lack of a clear description of the differences between the concepts of 'Central Europe' and 'Central and Eastern Europe' is a shortcoming in this work. The author has tended to make use of the former concept, the latter appears interchangeably. This is not a mistake - many previous authors writing about this subject in independent magazines and elsewhere did the same - but the two should be more clearly distinguished as in some cases the differences between the two 'projects' was essential, especially when comparing Polish and Czech debates. Poles took the East into account much more frequently in their perception of the region (although this was also done in Czech literature, as the title of Miroslav Kusý's text mentioned above shows). In Poland, the concept of 'Central and Eastern Europe' was used more frequently, whereas in the Czech Republic the higher frequency lay with 'Central Europe'. ${ }^{25} \mathrm{~A}$ difference in nomenclature usually precedes a different territorial definition of the region. In the Czech Republic 'Central Europe' is generally understood as the countries formerly a part of the Habsburg empire, whereas in Poland 'Central and Eastern Europe' is seen as the former territories of the Polish-Lithuanian Commonwealth. ${ }^{26}$ Poland's interest in

${ }^{25}$ Jerzy Kłoczowski, 'Europa Środkowo-Wschodnia jako przedmiot badań', $K H$, 120, 2013, 4, pp. 833-43 (p. 835).

${ }^{26}$ Tomasz Stryjek, 'Europa Środkowa (Środkowo-Wschodnia), czyli o pochwale różnorodności i komparatystyki', KH, 120, 2013, 4, pp. 761-91 (p. 796). 
the East resulted from the significance of the borderlands as an element in Polish identity, from an idea of Jagiellonian Poland and the policy of Jerzy Giedroyc and Kultura, most simply described as a sympathetic view towards Ukraine, Lithuania and Belarus (and their aspirations to independence).

Parfianowicz-Vertun is clearly aware of these problems. Furthermore as I already mentioned she deals extensively with the significance of the "borderlands' (Kresy) tradition versus the influence of Kultura, but she seems to forget about this distinction when comparing Polish and Czech debates. She suggests that unlike Czech samizdat, in Polish underground publishing there were few texts analysing the problem of Central Europe in a comprehensive manner, and they tended to do so rather in a cultural than a political sense. Considering the heightened dealings of Polish oppositionists with the East compared with those in Czechoslovakia could direct the author's research to different press titles, such as Lublin Spotkania - probably the first clandestine magazine which dealt extensively with eastern themes. In Spotkania Włodzimierz Mokry wrote about Eastern Europe alongside several other authors. An inquiry into titles such as Międzymorze (Between-Seas/Intermarium) and Niepodległość (Independence) and the press of Solidarność Walcząca (Fighting Solidarity) or Konfederacja Polski Niepodległej (Confederacy of Independent Poland) (both environments which attached great importance to eastern issues) would also have been worth considering. Perhaps analysis of these may confirm some of the author's conclusions, however reading Spotkania in particular may have forced her to slightly revise her conclusion about the former direction of Polish research being political and not cultural. This book should inform readers about the borders this region had for Czech and for Polish opposition; sadly this is missing.

Generally it seems that more extensive research on press sources would have allowed the author to present certain conclusions in a more nuanced form, and also provide interesting facts to confirm these conclusions. Parfianowicz-Vertun writes: 'A characteristic feature of publications from that period is that we do not encounter many texts problematizing the idea of Central Europe, or devoted to the search for some specific cultural entity. Most commentators writing in the underground press were focused on political situations in the region and the circumstances of their development' (p. 312). ${ }^{27}$ The author draws these conclusions based primarily on reads of $A B C$ and Obóz (The Camp) which, as she herself notes, aimed at presentation of opposition voices from foreign countries and these nations learning about each other. She notes that these discussions in the independent press had a predominantly cultural profile, but with the reservation that they tended to concentrate on literature, not an aspect of cultural

27 'Charakterystycznym rysem wydawnictw z tego okresu jest to, że nie znajdziemy w nich wielu tekstów problematyzujących samą ideę Europy Środkowej ani też poświęconych poszukiwaniu jakiejś specyficznej kulturowej całości. Uwagę większości komentatorów w drugim obiegu przykuwała sytuacja polityczna w regionie i scenariusze jej rozwoju'. 
identity that most interests her. Parfianowicz-Vertun occasionally refers to Brulion (The Writing Pad), but perhaps using such Polish magazines like Obecność (Presence), Wezwanie (The Call) or Czas Kultury (Time of Culture) could have extended her analyses. For example a 1980 publication of Biuletyn Dolnoślaski (Lower Silesia Bulletin) played host to an important discussion concerning Jan Waszkiewicz' text 'Jaka Europa' (What Europe).

Even in the magazine Obóz which Parfianowicz-Vertun has analysed, it is possible to find an overlooked text which seems important considering her chosen subject, a 1998 article by Robert Bogdański titled 'Europa Środkowa w Europie Środkowej dziś - mit i postulat' (The Central Europe in Central Europe Today the Myth and the Postulate). It focused not only on political concepts but also cultural ones. The author asked what Central Europe meant for intellectuals from small communist European states. He mentioned a number of common experiences which resulted in inhabitants of the region better understanding each other. Bogdański wrote: 'Central Europe is a salvation for us and it plays a defensive role. From the East it is our sign of otherness and independence. From the West a sign of our connection but, at the same time distinctiveness and our equality. Therefore - according to my understanding - Central Europe is the artificial creation of intellectuals. It is speculation. Its existence in our minds is the result of fear and has a defensive character. It is not an entity which exists in a natural way and which we've simply named. It is rather a name itself, without an entity'. ${ }^{28}$ Bogdański's words are in line with Parfianowicz-Vertun's apt observation on the textual nature of the Central Europe project. This text could be compared with the essay by Kusý mentioned earlier, who wrote that it is mainly in the West that a common identity of Central Eastern Europeans is written about, whilst besides belonging to one bloc, this community does not yet in fact exist. ${ }^{29}$ The two approaches vary slightly in their perception of the concept's genesis, but for both of them it is rather an idea than a description of reality.

Despite these criticisms the analysis conducted by Parfianowicz-Vertun is usually apt and very credible even though based on limited material. She mentions Polish Krytyka (Criticism) and Czech Spektrum (Spectrum) as magazines which initiated underground debates on the subject. Polish readers will find the

28 'Europa Środkowa jest dla nas ratunkiem i pełni funkcję obronną. W stosunku do Wschodu jest naszym znakiem inności i niezależności. W stosunku do Zachodu sygnałem naszej łączności, a jednocześnie odrębności i niepodporządkowania. Stąd w moim rozumieniu - Europa Środkowa jest sztucznym tworem intelektualistów. Jest spekulacją. Jej istnienie w naszej świadomości wypływa ze strachu, ma charakter obronny. Nie jest ona bytem istniejącym w sposób naturalny, któremu jedynie nadaliśmy nazwę. Jest to raczej sama nazwa, bez bytu', Aleksander Romert [Robert Bogdański], 'Europa Środkowa w Europie Środkowej dziś - mit i postulat', in Na przekór geopolityce, pp. 213-14. On using the notion of Central Europe as a symbolic mark of cutting off the connection with Russia and USSR, see: Maciej Górny, 'Użyteczność i granice: Europa Środkowo-Wschodnia jako narzędzie badawcze', KH, 120, 2013, 4, pp. 801-08 (p. 803); Kizwalter, ““Zachód porwany...”, p. 828.

${ }^{29}$ Kusý, ‘We Central East Europeans', p. 165. 
history of the Czech samizdat magazine Střední Europa (Central Europe), its title clearly reflecting the editors' focus, interesting. This magazine, in contrast to dominant Czech narratives of the time, referred not to middle-class and Protestant or atheistic traditions but to monarchist and Catholic ones. The theme locality which this Prague-published magazine raises is interesting - is was published in Moravia and perceived this region as quintessential Central Europe.

Weronika Parfianowicz-Vertun deals extensively with the operation of independent culture networks in which discussions about Central Europe took place. She is precise in her observation of different traditions for creating underground texts. Polish tradition centred around the conspiracy press originating from the time of the Second World War (or even of the partitions), Czech - to independent literary almanacs. The significance of these different traditions can be seen in the differences emphasized by the author between politically-focused Polish publishing and the more literature-focused Czech. The author rightly mentions the differing social reception of both movements and differentiates underground publishing from samizdat. This latter term has been used by Western researchers also in reference to Poland, but in Poland has not been popular. Accepting this differentiation, Parfianowicz-Vertun formulates the thesis that the use of a different concept in Poland from that of the other states Soviet bloc is the result of an evaluation which has found the Polish independent publishing movement to be exceptional compared with analogous phenomena which developed in other communist states (p. 88). It is possible to agree with this in part - moreover there is a strong basis exist to emphasize an exceptional Polish output in this area. In Polish underground publishing approximately ten times more magazine titles were published than in all the other countries taken together. ${ }^{30}$ The idea of samizdat refers to a method of creating text: the rewriting of them by subsequent readers, which in Poland was continued only for a short time during certain periods (1976-77 and at the beginning of martial law). It is also worth emphasizing in this context that the concept of a 'secondary distribution network' (underground publishing) was initially coined by the authorities and has pejorative connotations (something lesser than the first, that is official distribution network). ${ }^{31}$ For instance, when the communist politician Józef Tejchma wrote in his diary about Stefan Kisielewski's text published 'in some kind of secondary distribution network', it was an expression of disparagement. ${ }^{32}$

From Parfianowicz-Vertun's discussion of Polish underground publishing there is sometimes the impression that she treats it more critically than Czecho-

30 See: Jan Olaszek, Rewolucja powielaczy: Niezależny ruch wydawniczy w Polsce 19761989, Warsaw, 2015, p. 332.

${ }^{31}$ See statements by Jan Skórzyński and Adam Mielczarek in the discussion 'Znaczenie drugiego obiegu wydawniczego w PRL', in Drugi obieg w PRL na tle samizdatu, pp. 565,570 .

${ }^{32}$ Józef Tejchma, W kręgu nadziei i rozczarowań: Notatki dzienne z lat 1978-1982, Warsaw, 2003, p. 69. 
slovakian samizdat. She considers this latter topic to be more interesting, more focused on literature and culture than on politics, and she prefers to analyse it. It is a big advantage from the Polish readers' perspective - the initiatives of Poland's southern neighbours described by her are not commonly known here even to researchers of recent history. It does not mean that the author takes an uncritical view of Czech samizdat. She perceives the crisis of that literary world and its limitations. Yet she views Polish independent publishing as greatly saturated by the poetics of martyrdom. It is possible to agree with this in part, but she should also take account of initiatives which had nothing in common with such drama and strongly opposed it (the conservative-liberal Res Publica or a large portion of publications from the Workers' Defence Committee (KOR)).

The author is also right in the way she describes the output of Polish researchers on underground publishing. It has often been emotional, with no distance, as some historians have appeared to identify with the ideologies of the creators of the publishing networks. Parfianowicz-Vertun on the whole opposes such narratives. Her mode of deconstructing the myth of underground publishing is legitimate and much needed, as a critical and scientific approach. Occasionally however she has taken it too far - in Europa Środkowa w tekstach $i$ działaniach Parfianowicz-Vertun quotes with approbation the opinion of literary critic Leszek Bugajski from 1989's Polityka weekly, who suggests that underground publishing had almost exclusively political goals, not artistic ones. Our knowledge about the history for example of Zapis (Ban) or Puls (Pulse) magazines contradicts this opinions. The reader should be informed that Bugajski was an author who was very critical of independent publishing, and his words cannot be considered free from political sentiment, especially having written them in 1989 when underground publishing was still ongoing. Instead the author states 'This thesis seems to comply with the reality of unauthorized publishing houses established in Poland' (p. 81). This is at odds with the deliberately apolitical attitude of a large part of the opposition movement, of which the author is aware as she writes about it on the next page (p. 82).

Several other opinions on Polish underground publishing are presented in an equally strong way and without nuance. For example, the author writes of the boring and mono-thematic character of underground press. There is an element of fact since one of the basic agendas of underground press - not only Polish, but also Russian Khronika tekushchikh sobytii (Chronicle of Current Events) was to document repressions. Reading dozens of similar notes about arrests is not very interesting from a cognitive point of view but nonetheless one of this press' functions. The problem lies in the fact that with respect to Polish titles, the author refers to examples from characteristically fact-focused publications, such as Tygodnik Mazowsze (Mazovia Weekly), whereas she should for Polish and Czech ones alike take into account also other types of magazine such as purely cultural or literary ones.

The same can be said of her treatment even of the appearance of particular magazines. Parfianowicz-Vertun mentions that Czech oppositionists put greater emphasis on the aesthetics of their publications than the Poles. The author 
models this to a deliberate Polish strategy and a the idea of a 'patriotic-conspiracy' which left no room for emphasis on graphic layout (p. 99). I cannot agree with such a description. Practical considerations were decisive here; Polish magazines, often printed in many places and distributed among a broad circle of recipients could not afford to lay aside much budget for design. But a majority of them tried to improve their visual side. Some such as Przeglad Wiadomości Agencyjnych (Review of Agency News) which contained many photos, or exclusive bibliophile issues of Puls, stood out firmly with respect to graphic outlay, and it would have been good to showcase these examples.

The main problem with these comparisons lies in the difference in scale between Polish underground publishing and Czech samizdat. The latter was a much smaller operation, so that non-political magazines, more originally edited and caring more about their visual side, probably constituted a greater part of the whole than they did in Poland. If one looks at the topic in absolute numbers the situation may look different. Writing about these problems the author falls victim to the stereotype which states that a significant proportion of Polish magazines were created and driven by workers, whereas in fact even those papers which directly addressed this group were usually composed by intelligentsia, see: KOR papers Robotnik (Worker) or Wola ${ }^{33}$ weekly (distributed in the workers enterprises, but created by Polish philology and cultural studies graduates participating in the seminars of Professor Andrzej Mencwel - incidentally the supervisor of Parfianowicz-Vertun's doctoral dissertation). Omitting this fact gives the impression of a dichotomous division into the artistic and intellectual Czech samizdat and the worker-originated, political Polish underground publishing. The reality was more complex.

The author's observations on the limited reception of underground texts in the West can be subject to polemics. Parfianowicz-Vertun writes: 'Obviously Western academic and emigration circulation networks and underground publishing circulation networks intertwined in a variety of ways, reacted to each other and complemented each other to such extent that sometimes clear differentiations are not possible. But where the flow of ideas, texts and authors between these two circulation networks was rather smooth and mutual, in the case of underground magazines and samizdat we mostly speak about a one-way flow' (p. 69). ${ }^{34}$ This may be true regarding the debates on 'Central Europe', but in general it is difficult to agree with this opinion. Research by Friderike Kind-

${ }^{33}$ Wola in old-Polish means freedom. Nowadays it is the name of the Warsaw district, where this weekly was published.

34 'Oczywiście zachodnie obiegi akademickie i emigracyjne oraz nieoficjalny obieg wydawniczy na różne sposoby się przenikały, reagowały na siebie i wzajemnie się dopełniały, do tego stopnia, że niekiedy wyraźne rozgraniczenia nie są nawet możliwe. O ile jednak przepływ myśli, tekstów i autorów pomiędzy pierwszymi dwoma wyróżnionymi obiegami był dość płynny i wzajemny, o tyle w przypadku czasopism drugiego obiegu i samizdatu mówić możemy raczej o ruchu w jednym kierunku'. 
-Kovács shows that the exchange was, after all, two-way..$^{35}$ Even Jerzy Giedroyc, who on principle refused to publish any reprints in the Instytut Literacki of Paris, did publish the history of 'Solidarity' by Jerzy Holzer which had initially appeared in the underground publishing house Kragg (Cercle). It is worth taking into account that not only magazines but also Radio Free Europe, which broadcast many programmes, read or made reference to underground publications (as proved by the bulletins of the Polish section of RFE: Polish Independent Press Review or Polish Underground Extracts).

Despite the criticisms above, Weronika Parfianowicz-Vertun's book contains many inspiring observations relating to samizdat and underground publishing, and the differences between them. For example, there is her thesis on another function for underground literary magazines published in both countries. While Polish literary criticism has been treated briefly, for Czechoslovakia it is quite the opposite. This thesis could be more nuanced, given the plethora of debates in literary magazines on (which Dobrochna Dabert wrote about) the form and value of literature, and absence of masterpieces having come from underground publishing; ${ }^{36}$ still, it is possible that Czechs in fact did have a greater number of texts on literary criticism in their magazines. In the author's opinion, this difference resulted from the greater freedom of scientific and academic life in Poland, where in certain institutions and universities underground papers circulated almost openly or were the subject of academic discussion. In Czechoslovakia the literary underground did not have such a background. While in Poland academic life mixed frequently with the life of activism, in Czechoslovakia discussions about independent culture were conducted rather in the hospoda than at academic centres.

Other observations by the author relating to spatial factors - for example the role of dissidents' flats as substitutes for freedom - are similarly inspiring. She has analysed the memories of participants of free press circulation networks and writes 'An element which is repeated in narrations on the matter of creating texts is a motif of continuous movement. Paper is transported (she mentions that it was difficult to deliver reams of paper without raising suspicion) as well as whole printing machines and people ran in search of paint or spare machine parts. Texts are transported again once they are prepared. Physical movement is accompanied with a continuous movement of thoughts - continuous planning, what, how, where, when and to whom to deliver or collect from' (p. 94). ${ }^{37}$

35 See: Frederike Kind-Kovács, Written Here, Published There: How Underground Literature Crossed the Iron Curtain, Budapest, 2014.

${ }^{36}$ Dobrochna Dabert, Między wizja a spetnieniem: Profile ideowe i artystyczne czasopism literackich $w$ drugim obiegu wydawniczym 1982-1989, Poznań, 2014, p. 94.

37 'Tym, co powraca w narracjach dotyczących sfery wytwarzania tekstów, jest motyw ciągłego ruchu. Przewozi się papier (i zwraca uwagę na to, że ciężko dostarczyć ryzy papieru, nie wzbudzając niczyich podejrzeń) i całe maszyny drukarskie, biega w poszukiwaniu farby albo części do maszyn. Transportuje gotowe teksty. Fizycznemu przemieszczaniu towarzyszy ciągły ruch myśli - nieustające planowanie, co jak, gdzie, kiedy komu dostarczyć lub od kogo odebrać'. 
Participants in this movement played a variety of roles. One time they would write a political or literary manifesto, on another occasion they went to collect paper. 'Here the idea resurfaces that underground publishing was a kind of game, the course and result of which was uncertain. The active attitude of the recipient, who performs various roles in the network of creation and circulation of clandestine publications is also mentioned. He can be the author, copyeditor or distributor, and the more roles he is able to play the more desired a "player" he becomes' she writes (p. 95). ${ }^{38}$ Polish historians dealing with the opposition and sometimes focused on the detailed reconstruction of facts tend to overlook these issues.

Parfianowicz-Vertun argues that distribution barriers of samizdat and underground publications, the circulation of many versions of texts with distortions resulting from multiple translations, has influenced the reception of debates on Central Europe (probably to a greater extent in the case of the more elusive Czech samizdat publications than Polish underground publications). Readers sometimes received a text which had little resemblance to the original. The author is right stating that this circumstance should be taken into account.

The presentation of publications - often very small print, sometimes almost illegible, impacted on their reception. The author's comment on the tension between 'maniac reading' of independent publications and the 'torture' of reading the densely written pages is also acute. These circumstances did not facilitate criticism of what people read; contact with the texts in which the author is interested was more often based on emotions than intellectual work. This resulted in a short life span of the vast majority of texts about Central Europe published underground in Poland and Czechoslovakia.

The book should present its most interesting element more strongly namely the relation between its analysis of the debates on Central Europe, and those about the role underground publishing and samizdat. Readers may feel a certain want for the relation between these two problems, in part due to a very laconic ending to the work. Despite the criticisms and reservations of this review - which always surface more in a review than praises - the work deserves to be praised and recommended. When a work's subject is treated by the author in a broad way, certain omissions in the selection of literature and sources are inevitable, and a proportional balance of material relating to both countries is very difficult to achieve.

Weronika Parfianowicz-Vertun's book will be useful and inspiring for a number of groups of readers. Historians will also be reminded of some ideas forgotten from the output of underground publishing in Poland and Czechoslovakia, which has been rarely used by researchers.

38 'Powtarza się tu intuicja, że niezależny obieg wydawniczy był pewnego rodzaju grą, której przebieg i rezultat pozostawał niepewny. Wskazuje się także na aktywną postawę odbiorcy, który w sieci wytwarzania i krążenia niezależnych publikacji zajmuje zmienne pozycje, może być autorem, twórcą kopii lub dystrybutorem, a im więcej ról jest w stanie na siebie przyjąć, tym bardziej pożądanym "graczem" się staje'. 
To historians of the opposition or underground publishing it may bring up interesting traces relating, for example, to aspects of the operation of the underground publishing phenomenon in politics and culture which have been on the whole avoided by them, such as the significance of spaces or the objects which were used, which historians, as opposed to anthropologists, rarely analyse. Another value of the book is its complementary approach, combining concurrent examination of texts and practices, and especially comparison of the same phenomenon occurring in two countries from the Soviet bloc, which allows for observing how cultural conditions influenced societies governed by systems which were ostensibly very similar.

(Translated by Elżbieta Petrajtis-O'Neill) (Proofreading by Yelizaveta Crofts)

\section{Summary}

The text deals with the post-war history of Poland and Czechoslovakia in the 1970s and 1980s. It contains the author's reflections on the book by Weronika Parfianowicz-Vertun Europa Środkowa w tekstach i działaniach: Polskie i czeskie dyskusje ([The Notion of Central Europe in Texts and Actions: Polish and Czech Debates] Warsaw: Wydawnictwa Uniwersytetu Warszawskiego, 2016). The book shows the way samizdat influenced the development and reception of debates on Central Europe in Poland and Czechoslovakia. The author of the review article raises several of the book's valuable points. They include the highly original anthropology-oriented approach of the author, who focuses on cultural practices connected with creating and reading texts distributed in the underground network. Thanks to this many interesting problems become apparent which researchers who focus solely on political aspects of the history of opposition and dissident movements tend to overlook. It's important also to mention the author's good knowledge of independent culture in Czechoslovakia. Although the author of the review highlights certain shortcomings of the publication (relating to the selection of sources and literature, lack of clear differentiation between Central Europe and Central and Eastern Europe, and hasty conclusions regarding comparison of the samizdat output of both countries), the overall evaluation is decidedly positive. The book will turn attention back to the forgotten output of Poland and Czechoslovakia's publishing underground, too rarely used by researchers. Historians of the opposition of underground publishing may derive suggestions relating, for example, to aspects which have been overlooked of the operation of underground publishing in the political and cultural field. Among other values of the book one an approach combining the concurrent analysis of texts and social practices in two states of the Soviet bloc which were ostensibly similar is also noteworthy.

(Translated by Elżbieta Petrajtis-O'Neill) (Proofreading by Yelizaveta Crofts) 


\section{Bibliography}

Ash, Garton, 'Does Central Europe Exist?', New York Review of Books, 9 October 1986.

Bielec, Dorota, Sprawy czeskie w polskich drukach drugiego obiegu, Cracow: Wydawnictwo Uniwersytetu Jagiellońskiego, 2008.

Blažek, Petr, 'Solidarita se Solidaritou: Opoziční hnutí v Československu a vyhlášení polského "válečného stavu” v prosinci 1981', in Od rywalizacji do wspótpracy: Relacje polsko-czeskie w badaniach młodych historyków z Polski i Republiki Czeskiej, ed. Dariusz Dąbrowski, Wrocław: Kolegium Europy Wschodniej, 2003, pp. 245-65.

Česká a polská samizdatová literatura / Czeska i polska literatura drugiego obiegu, ed. Libor Martinek and Martin Tichý, Opava: Slezská univerzita, Filozoficko-př́írodovědecká fakulta, Ústav bohemistiky a knihovnictví, 2004.

Choma-Jusińska, Małgorzata, Środowiska opozycyjne na Lubelszczyźnie 1975-1980, Warsaw and Lublin: Instytut Pamięci Narodowej, 2009.

Dabert, Dobrochna, Między wizja a spełnieniem: Profile ideowe i artystyczne czasopism literackich $w$ drugim obiegu wydawniczym 1982-1989, Poznań: Wydawnictwo Naukowe Uniwersytetu im. Adama Mickiewicza, 2014.

Drugi obieg w PRL na tle samizdatu w państwach bloku sowieckiego po 1956 roku, ed. Przemysław Gasztold-Seń, Natalia Jarska and Jan Olaszek, Warsaw: Instytut Pamięci Narodowej, 2016.

Feindt, Gregor, Auf der Suche nach politischer Gemeinschaft: Oppositionelles Denken zur Nation im ostmitteleuropäischen Samizdat 1976-1992, Berlin: De Gruyter Oldenbourg, 2015.

Friszke, Andrzej, 'Czasopisma społeczno-kulturalne “drugiego obiegu” wydawniczego', in Czasopisma społeczno-kulturalne w okresie PRL, ed. Urszula Jakubowska, Warsaw: Fundacja Akademia Humanistyczna; Instytut Badań Literackich PAN, 2012, pp. 383-462.

Glanc, Tomáš, ‘Samizdat jako médium', Souvislosti, 2013, 3, pp. 183-93.

Górny, Maciej, 'Użyteczność i granice: Europa Środkowo-Wschodnia jako narzędzie badawcze', Kwartalnik Historyczny, 120, 2013, 4, pp. 801-08.

Jasiński, Łukasz, Kwestie międzynarodowe w myśli opozycji demokratycznej w PRL 1976-1980, Gdańsk: Europejskie Centrum Solidarności, 2009.

Kamiński, Łukasz, 'Opozycja w Europie Środkowo-Wschodniej w latach 19451989 - droga do syntezy dziejów’, in Opozycja antykomunistyczna w krajach bloku wschodniego w latach 1945-1989, ed. Krzysztof Łabędź and Małgorzata Świder, Cracow: Księgarnia Akademicka, 2014, pp. 9-19.

Kamiński, Łukasz, Petr Blažek and Grzegorz Majewski, Ponad granicami: Historia Solidarności Polsko-Czechosłowackiej, Wrocław: Oficyna Wydawnicza Atut, 2009.

Kenney, Padraic, A Carnival of Revolution: Central Europe 1989, Princeton, NJ: Princeton University Press, 2002.

Kind-Kovács, Frederike, Written Here, Published There: How Underground Literature Crossed the Iron Curtain, Budapest: Central European University Press, 2014. 
Kizwalter, Tomasz, “"Zachód porwany...”, Kwartalnik Historyczny, 120, 2013, 4, pp. 825-31.

Kłoczowski, Jerzy, 'Europa Środkowo-Wschodnia jako przedmiot badań', Kwartalnik Historyczny, 120, 2013, 4, pp. 833-43.

Kobus, Artur, My i oni: Opozycja polityczna w PRL wobec analogicznych ugrupowań demokratycznych w Europie Środkowo-Wschodniej lat 80. XX wieku: Kontakty, wspótpraca, podobieństwa, Łódź: Wydawnictwo Uniwersytetu Łódzkiego, 2012.

Komaromi, Ann, Uncensored: Samizdat Novels and the Quest for Autonomy in Soviet Dissidence, Evanston, IL: Northwestern University Press, 2015.

Kulla, Albert, and Imrich, Gazda, 'Samizdat Periodicals before 1989 in Former Czechoslovakia', in Advances in Communication and Mass Media Research, ed. Yorgo Pasadeos, Athens, GA: Athens Institute for Education and Research, 2010, pp. 35-43.

Kundera, Milan, 'The Tragedy of Central Europe', New York Review of Books, 26 April 1984.

Kusý, Miroslav, 'We Central East Europeans', in Good-bye, Samizdat: Twenty Years of Czechoslovak Underground Writing, ed. Marketa Goetz-Stankiewicz, Evanston, IL: Northwestern University Press, 1992, pp. 160-165.

Na przekór geopolityce: Europa Środkowo-Wschodnia w myśli politycznej polskiej opozycji demokratycznej 1976-1989, ed. Jan Skórzyński, Warsaw: Centrum Obsługi Kancelarii Prezydenta Rzeczypospolitej Polskiej, 2014.

Olaszek, Jan, Rewolucja powielaczy: Niezależny ruch wydawniczy w Polsce 1976-1989, Warsaw: Trzecia Strona, 2015.

Poslední, Petr, ‘Czesko-polski kontekst literacki (1970-1979)', Porównania, 7, 2010, pp. 97-111.

Ritter, Rüdiger, 'Preparing the Postcolonial Situation: Polish Drugi Obieg Periodicals, the Europe Topic and the Question of Poland's Eastern Europe', Porównania, 13, 2013, 13, pp. 61-79.

Samizdat, Tamizdat, and Beyond: Transnational Media During and After Socialism, ed. Friderike Kind-Kovács and Jessie Labov, New York and Oxford: Berghahn, 2012.

Skilling, Harold Gordon, Samizdat and an Independent Society in Central and Eastern Europe, Columbus: Ohio State University Press, 1989.

Sowiński, Paweł, Zakazana ksiażka: Uczestnicy drugiego obiegu 1977-1989, Warsaw: Instytut Studiów Politycznych PAN, 2011.

Stryjek, Tomasz, ‘Europa Środkowa (Środkowo-Wschodnia), czyli o pochwale różnorodności i komparatystyki', Kwartalnik Historyczny, 120, 2013, 4, pp. 761-91.

Tejchma, Józef, W kręgu nadziei i rozczarowań: Notatki dzienne z lat 1978-1982, Warsaw: Projekt, 2003.

Underground Publishing and the Public Sphere: Transnational Perspectives, ed. Jan C. Behrends, Thomas Lindenberger, Wien and Münster: LIT Verlag, 2014. 
Bi o gra phy: Jan Olaszek - Doctor of Humanities, specialist in history, adjunct in the Institute of Political Studies, Polish Academy of Sciences and senior specialist in the Historical Research Office of the Institute of National Remembrance dealing with the history of opposition and dissident movements in Central and Eastern Europe and the history of underground publishing and samizdat. E-mail: olaszekjan@gmail.com. 